\title{
Two Naturally Occurring Transposons Indistinguishable from Tn7
}

\author{
By P. T. BARTH AND NAOMI DATTA \\ Department of Bacteriology, Royal Postgraduate Medical School, Du Cane Road, \\ London WI 2 oHS
}

(Received I6 February 1977; revised 26 April 1977)

Two plasmids from different sources, determining trimethoprim and streptomycin resist-
ances, harbour transposons which we designate $\operatorname{Tn} 7 \mathrm{I}$ and $\operatorname{Tn} 72$. These transposons are
indistinguishable from $T n 7$ in the resistances determined, in their molecular masses and in
the number and relative positions of their sites susceptible to the restriction enzymes EcoRI,
HindIII and BamHI. We conclude that $\operatorname{Tn} 7$ has been naturally spread among plasmids.

\section{INTRODUCTION}

A transposon is a specific DNA sequence carrying a recognizable genetic determinant or determinants, such as drug resistances, that is freely transposable from one replicon to another. Transposition is a non-reciprocal event that occurs equally in the presence or absence of the requirements of normal recombination, i.e. a functional $\operatorname{rec} A$ gene and regions of extensive homology between the participating DNA sequences (Heffron, Rubens \& Falkow, 1975 $a$; Kopecko \& Cohen, 1975; Gottesman \& Rosner, 1975; Barth et al., 1976).

Since the original recognition of a transposon carrying an ampicillin resistance determinant (TnA or TnI) from plasmid RP4 (Hedges \& Jacob, I974), many others have been recognized (for review, see Cohen, 1976). Because of their ubiquity and ability to move freely from plasmid to plasmid, transposons are thought to have played a large part in the rapid evolutionary spread of bacterial drug resistances during the last two decades. TnA certainly appears to be widely spread: its DNA sequence homology (Heffron et al., 1975b) is present in, and its TEM $\beta$-lactamase (Matthew \& Hedges, I976) is produced by a variety of unrelated plasmids that confer ampicillin resistance.

We have recently been studying transposon $\mathrm{C}$ [ $\mathrm{TnC}$, now redesignated $\mathrm{Tn} 7$ by a selfappointed committee (Cohen, 1976)]. Tn7, derived from R483, carries determinants for resistances to trimethoprim $\left(\mathrm{Tp}^{\mathrm{r}}\right)$ and streptomycin/spectinomycin $\left(\mathrm{Sm}^{\mathrm{r}}\right)$ (Barth et al., 1976). We were interested to find out whether $\operatorname{Tn} 7$ was also spread amongst other naturally occurring plasmids. We therefore looked for other plasmids that conferred $\mathrm{Tp}^{\mathrm{r}}$ and $\mathrm{Sm}^{\mathrm{r}}$ and tested them for the transposability of these determinants. Two such plasmids were found. We measured the molecular weights and mapped the restriction enzyme-susceptible sites on the transposons they harboured. On these criteria, the two new transposons were indistinguishable from $\operatorname{Tn} 7$.

\section{METHODS}

Materials and media. Materials and growth media were as described previously (Coetzee, Datta \& Hedges, 1972; Barth \& Grinter, 1974). Restriction enzymes were obtained from Miles Laboratories.

Bacterial strains. Strains of Escherichia coli $\mathrm{KI} 2$ used were: w3I I OT- (thy dra); 553 (F- pro met) (Bachmann, 1972); J53-I, a nalidixate-resistant derivative of $\mathrm{J} 53$ (Coetzee et al., 1972); HH26 (Barth et al., 1976) and HH27. Strains $\mathrm{HH}_{2} 6$ and $\mathrm{HH}_{2} 7$ are $\operatorname{rec} A$ thy ${ }^{+}$derivatives of $\mathrm{C60OT}^{-}$and $\mathrm{w}_{3}$ I IOT $^{-}$respectively. The $r e c A$ marker was introduced from the $\mathrm{Hfr}$ recA strain MAI079, selecting for Thy ${ }^{+}$transconjugants. The Proteus mirabilis strain was PMI3 (Coetzee, 1972). 


\section{Table I. Bacterial plasmids}

\begin{tabular}{|c|c|c|c|c|}
\hline \multirow[b]{2}{*}{ Plasmid } & \multirow[b]{2}{*}{ Characters conferred* } & \multicolumn{2}{|c|}{ Origin } & \multirow[b]{2}{*}{ References } \\
\hline & & Bacterial & $\begin{array}{c}\text { Geo- } \\
\text { graphical }\end{array}$ & \\
\hline $\mathrm{R} 483$ & $\mathrm{Tp}^{\mathrm{r}} \mathrm{Sm} / \mathrm{Sp}^{\mathrm{r}}$ ColIa I pili IncI $\alpha$ & $\begin{array}{l}\text { Escherichia } \\
\text { coli }\end{array}$ & Kent & Datta \& Barth (I976) \\
\hline $\mathrm{R}_{72 \mathrm{I}}$ & $\mathrm{T} \mathrm{p}^{\mathrm{r}} \mathrm{Sm} / \mathrm{Sp}^{\mathrm{r}}$ I pili IncI $\delta \dagger$ & E. coli & London & Jobanputra \& Datta (1974) \\
\hline $\mathrm{pBW}_{\mathbf{I}}$ & $\mathrm{Tp}^{\mathrm{r}} \mathrm{Sm} / \mathrm{Sp}^{\mathrm{r}}$ I pili IncI $\delta \ddagger$ & E. coli & Herts & B. West (unpublished) \\
\hline $\mathrm{RP}_{4}$ & $\mathrm{Ap}^{r} \mathrm{Tc}^{r} \mathrm{Km}^{r}$ IncP & $\begin{array}{c}\text { Pseudomonas } \\
\text { aeruginosa }\end{array}$ & Glasgow & Datta et al. (I971) \\
\hline $\mathrm{R}_{702}$ & $\mathrm{Sm} / \mathrm{Sp}^{\mathrm{r}} \mathrm{Tc}^{\mathrm{r}} \mathrm{Km}^{\mathrm{r}} \mathrm{Su}^{r}$ IncP & $\begin{array}{l}\text { Proteus } \\
\quad \text { mirabilis }\end{array}$ & U.S.A. & Hedges \& Jacob (I974) \\
\hline
\end{tabular}

Bacterial plasmids used are given in Table $\mathrm{I}$.

Isolation of transposition plasmids. Escherichia coli $\mathrm{K} 12 \mathrm{~J} 53$ strains were constructed carrying two plasmids, the prospective donor plasmid, $\mathrm{R}_{72} \mathrm{I}$ or $\mathrm{pBW}$, and the prospective recipient, $\mathrm{RP}_{4}$. These strains were mated with $P$. mirabilis, and the mixtures were plated on MacConkey agar incorporating trimethoprim (Io $\mu \mathrm{g} \mathrm{m}^{-1}$ ), $4 \%(\mathrm{v} / \mathrm{v})$ lysed horse blood (to allow the trimethoprim to be actively antibacterial in the MacConkey medium) and polymyxin B $\left(25 \mu \mathrm{g} \mathrm{ml}^{-1}\right)$ (to prevent the growth of $E$. coli while permitting that of $P$. mirabilis). Trimethoprim-resistant $P$. mirabilis transconjugants, recognized as $\mathrm{Lac}^{-}$colonies on the selection plates, were purified on MacConkey plates, again incorporating Tp and lysed blood. Purified clones were identified by biochemical tests and their resistance patterns were defined by disc tests. This method selects transposition plasmids when the transposon donor is unable to replicate in $P$. mirabilis (see Results).

Plasmids were transferred from $P$. mirabilis to $E$. coli $\mathrm{K} \mathrm{I}_{2} \mathrm{~J} 53$-1 by a similar technique, using nalidixic acid in place of polymyxin.

Retransposition from plasmid to chromosome. $\mathrm{RP}_{4}$ plasmids containing a transposon were transferred by conjugation to the recA strain, HH26. R702, another IncP plasmid, was then introduced by selection of sulphonamide-resistant transconjugants. Isolated clones were tested for retention of $\mathrm{Tp}^{\mathrm{r}}$; such clones were tested for the markers of $\mathbf{R P}_{4}$. The genetic location of $\mathrm{Tp}^{\mathrm{r}}$ (chromosomal or plasmid) was established by tests for transfer frequency and linkage.

Isolation of plasmid DNA. Strains of $\mathrm{w}_{3} \mathrm{I} \mathrm{I} \mathrm{IOT}^{-}$carrying plasmids were labelled with $\left[{ }^{3} \mathrm{H}\right]-$ or $\left[{ }^{14} \mathrm{C}\right]$ thymine, lysed with sarkosyl, and their supercoiled DNA was isolated by ethidium bromide-CsCl equilibrium centrifugation as previously described (Barth \& Grinter, 1974). The isolated DNA was dialysed overnight against a continuous flow of $51 \mathrm{TNE}$ buffer (50 mM-Tris/50 mM-NaCl/I mM-EDTA, pH 7.5).

Cleavage of plasmid DNA with restriction enzymes. Plasmid DNA was supplemented with 0.125 vol. of $0.1 \mathrm{M}-\mathrm{MgCl}_{2} / \mathrm{I} \mathrm{M}$-Tris buffer, $\mathrm{pH} 7.5$, plus $0.0 \mathrm{I}$ vol. of the appropriate restriction enzyme, and incubated at $37^{\circ} \mathrm{C}$ for I h.

Sucrose gradient sedimentation analysis. Molecular weights of plasmid DNAs were measured by sedimentation, together with a suitable marker DNA, through neutral sucrose gradients. These were isokinetic (apprex. 5 to $20 \%, \mathrm{w} / \mathrm{v}$ ) and generated by a freeze-thaw method (Barth \& Grinter, 1977). Molecular weights were calculated as described by Barth \& Grinter (1974).

\section{RESULTS}

\section{Identification of plasmids possibly harbouring Tn7}

We hold a collection of over Iooo R plasmids, collected from many bacterial and geographical sources. Among these, only 30 determine $\mathrm{Tp}$ resistance. Of these, only three determine linked $\mathrm{Tp}$ and $\mathrm{Sm}$ resistance, namely $\mathrm{R}_{483}, \mathrm{R}_{72 \mathrm{I}}$ and pBW I (Table I). 
Table 2. Molecular masses of intact and restriction enzyme-cloven transposition plasmids

Molecular masses (Mdal) were measured by sucrose gradient analyses using ${ }^{3} \mathrm{H}$-labelled R P4-Tn7 I or RP4-Tn72 and ${ }^{14} \mathrm{C}$-labelled $\mathrm{RP}_{4}$ as a marker. The insertion sites refer to the map of $\mathrm{RP}_{4}$ given in Fig. I.

\begin{tabular}{|c|c|c|c|}
\hline Plasmid & & $\mathrm{RP}_{4}-\mathrm{Tn}_{7 \mathrm{I}}$ & $\mathrm{RP}_{4}-\mathrm{Tn} 72$ \\
\hline Molecular mass & & $44 \cdot 5$ & $44 \cdot 0$ \\
\hline EcoRI fragments & $\begin{array}{l}\text { I } \\
2\end{array}$ & $\begin{array}{l}29.9 \\
14.6\end{array}$ & $\begin{array}{l}30 \cdot 4 \\
14 \cdot I\end{array}$ \\
\hline Hind III fragments & $\begin{array}{l}\text { I } \\
2 \\
3\end{array}$ & $\begin{array}{r}39 \cdot 0 \\
3 \cdot 6 \\
I \cdot 9\end{array}$ & $\begin{array}{r}23 \cdot 6 \\
18 \cdot 9 \\
2 \cdot 0\end{array}$ \\
\hline Bam $\mathrm{HI}$ fragments & $\begin{array}{l}\text { I } \\
2 \\
3\end{array}$ & $\begin{array}{c}21 \cdot 9 \\
21 \cdot 9 \\
0.75\end{array}$ & $\begin{array}{c}37.9 \\
5.8 \\
0.75\end{array}$ \\
\hline Insertion site into $\mathrm{RP}_{4}$ & & $24 \cdot I$ & $8 \cdot 3$ \\
\hline
\end{tabular}

Test for the presence of transposons

Plasmid R483 was previously shown to contain $\mathrm{Tn}_{7}$ (Barth et al., I976). R72I and pBWI were found to be non-transferable to $P$. mirabilis strain PMI3, like other I-pilus-determining plasmids (Datta \& Hedges, 1972). This enabled us to demonstrate the transposition of resistance genes to $\mathrm{RP}_{4}$, a plasmid capable of replication in $P$. mirabilis. This method was used previously to detect transposition of $\mathrm{Tn} 7$ from $\mathrm{R}_{483}$ (Barth et al., 1976). Donor bacteria carrying both $\mathrm{RP}_{4}$ and either $\mathrm{R}_{72}$ I or pBW I were mated with strain PMI 3 ; selection was made for the transfer of $\mathrm{Tp}^{\mathrm{r}}$ (see Methods). All $\mathrm{Tp}^{\mathrm{r}}$ transcipients carried, not only the RP4 markers, but also the unselected $\mathrm{Sm}^{\mathrm{r}}$ marker. Resistant $P$. mirabilis transconjugants were used as donors to J53-I, selection being for $\mathrm{Tp}^{\mathrm{r}}$ and $\mathrm{Km}^{\mathrm{r}}$ separately. All E. coli transconjugants tested carried ApKmTcSmTpr, indicating that the $\mathrm{TpSm}$ resistance genes were transposed to $\mathrm{RP}_{4}$ from both $\mathrm{R}_{72} \mathrm{I}$ and $\mathrm{pBW}$, as previously shown with $\mathrm{R}_{4} 8_{3}$.

\section{Retransposition in a recA host}

We tested the ability of the $\mathrm{RP}_{4}$ derivatives, carrying $\mathrm{TpSm}^{\mathrm{r}}$ from $\mathrm{R}_{72 \mathrm{I}}$ or $\mathrm{pBW}$, to transpose these latter markers to another replicon in a recA host. $\mathrm{R} 702$, incompatible with $\mathrm{RP}_{4}$, was therefore transferred to $\mathrm{HH} 26$, carrying these derivatives. In approximately $50 \%$ of transconjugants, the resident $\mathrm{RP}_{4}$ plasmid, including its transposed $\mathrm{Tp}^{\mathrm{r}}$ marker, was eliminated. In the remainder, $T p^{r}$ was retained, although $R^{2} 4$, recognizable by its $A p^{r}$, had been eliminated. [Hedges \& Datta (1973) demonstrated a similar frequency of retention of the $\mathrm{Tp}^{\mathrm{r}}$ of $\mathrm{R}_{483}$, i.e. $\mathrm{Tn} 7$, when the incompatible plasmid JR66a was transferred to an $\mathrm{R}_{483^{+}}$strain.]

To determine the location of the retained $\mathrm{Tp}^{\mathrm{r}}$, clones carrying it were used as donors to another $\mathrm{rec} A$ strain, $\mathrm{HH}_{27}$, selecting for $\mathrm{Km}^{\mathrm{r}}$ (an $\mathrm{R} 702$ marker) or $\mathrm{Tp}^{\mathrm{r}}$. Transconjugants selected for $\mathrm{Km}^{\mathrm{r}}$ were rooo-fold more numerous than those selected for $\mathrm{Tp}^{\mathrm{r}}$, and of Io isolated $\mathrm{Km}$-selected clones, none was $\mathrm{Tp}$. All clones tested, selected on $\mathrm{Tp}$ plates, carried the resistance markers of R702. In these transconjugants, $T p^{r}$ was linked to $R 702$, as evidenced by co-transfer in conjugation. It was not possible, in these tests, to demonstrate $\mathrm{Sm} / \mathrm{Sp}^{\mathrm{r}}$, linked to $\mathrm{Tp}^{\mathrm{r}}$ in transposition, since it was masked by the $\mathrm{Sm} / \mathrm{Sp}^{\mathrm{r}}$ of $\mathrm{R} 702$.

\section{Plasmid molecular weights}

Parental plasmids. The molecular masses of plasmid DNAs isolated from strains carrying R72I and $\mathrm{pBW}$, determined by sucrose gradient analysis, were 48 and 45 Mdaltons (Mdal) respectively. Thus they are different from $\mathrm{R}_{483}$ (62 Mdal; Barth et al., 1976) and from each other. 


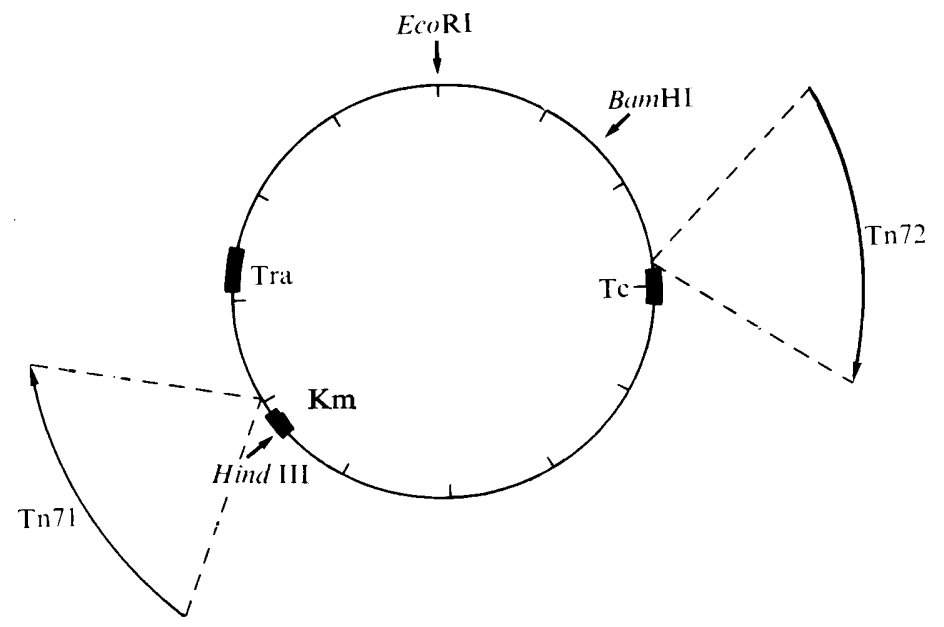

Fig. I. A map of plasmid RP4 showing the observed sites of insertion of Tn7I and Tn72. The positions of resistance genes, transfer genes and sites susceptible to restriction enzymes on $\mathrm{RP}_{4}$ were determined by Barth \& Grinter (1977). The positions and orientations of Tn7I and Tn72 were calculated from the data shown in Table 2, using the assumed position of the EcoRI site on each transposon described in the text. The internal scale is shown in 3 Mdal units.

Transposition plasmids. $\mathrm{RP}_{4}$ has a molecular mass of $36 \mathrm{Mdal}$. We have previously shown that transposition of $\mathrm{TpSm}^{\mathrm{r}}$ from $\mathrm{R}_{4} 83$ into $\mathrm{RP}_{4}$ leads to a molecular mass gain of about 8.5 Mdal which we have used as an estimate of the size of $\operatorname{Tn} 7$ (Barth et al., 1976). We measured the molecular mass of two plasmids derived from $\mathrm{RP}_{4}$ that had acquired the resistances of $\mathrm{R}_{72 \mathrm{I}}$ or $\mathrm{pBW}$ I as described above. They were 44.5 and $44.0 \mathrm{Mdal}$ respectively (Table 2) i.e. gains of 8.5 and $8.0 \mathrm{Mdal}$ above the molecular mass of RP4. These gains are, within experimental error, the same as that of $\operatorname{Tn} 7$. We designate these transposons from $\mathrm{R}_{72 \mathrm{I}}$ and $\mathrm{pBW} \mathrm{I}$ as $\mathrm{Tn} 7 \mathrm{I}$ and $\mathrm{Tn}_{72}$ respectively.

\section{Restriction enzyme sites}

EcoRI. We have previously shown that $\mathrm{Tn} 7$ and $\mathrm{RP}_{4}$ each have a single site susceptible to EcoRI, thus RP4-Tn7 transposition plasmids have two such sites. The molecular masses of the two DNA fragments obtained from EcoRI cleavage of such plasmids depend upon the site of insertion of Tn7 (Barth et al., 1976; Barth \& Grinter, 1977). RP4-Tn7I and RP4-Tn72 plasmid DNA samples were treated with EcoRI and analysed by sucrose gradient sedimentation. Each sample gave two DNA fragments (Table 2). Thus Tn7I and Tn72 each have a single Eco RI susceptible site.

HindIII. RP 4 has a single HindIII site whereas $\mathrm{Tn} 7$ has two, separated by $2 \cdot 0$ Mdal (Barth \& Grinter, I977). When RP4-Tn7I and RP4-Tn72 were treated with HindIII each gave three fragments including a fragment of about 2 Mdal (Table 2). Thus Tn7I and Tn72 each have two HindIII sites 2 Mdal apart. (The data for Tn7I, but not Tn72, could also be interpreted as indicating a distance of $3.6 \mathrm{Mdal}$ between its HindIII sites. In view of the other close similarities of Tn7r with Tn7 we think this possibility is less likely.)

BamHI. RP4 has a single BamHI site; Tn7 has two, separated by 0.7 Mdal (Barth \& Grinter, I977). The analyses of BamHI generated fragments of RP4-Tn7I and RP4-Tn72 show that Tn7I and Tn72 also have two cut sites separated by 0.75 Mdal (Table 2 ).

\section{Sites of insertion of Tn7I and Tn 72 into $R P_{4}$}

The combination of EcoRI and HindIII data for each plasmid allow one to calculate the site of insertion of its transposon on a circular map of $\mathrm{RP}_{4}$ (whereas the data from either 
enzyme alone do not discriminate between insertion sites suitably placed on either side of the $\mathrm{RP}_{4}$ cut site). The (EcoRI, HindIII and BamHI) restriction sites on $\mathrm{RP}_{4}$ have been located relative to one another, but precise mapping of transposon insertion depends upon knowing the position of one of the restriction sites on each transposon. The position of the EcoRI site on Tn7 was deduced to be about 2.7 Mdal from one of its ends (Barth \& Grinter, 1977). We have assumed this same position for Tn7I and $\operatorname{Tn} 72$ in order to calculate their insertion sites (Table 2, Fig. 1). This argument and method of calculation are fully expounded in Barth \& Grinter (1977).

\section{Relative positions of restriction sites on $T n 7 \mathrm{I}$ and $T n 72$}

The data on restriction fragments (Table 2) also enable one to calculate the relative positions of the restriction sites on Tn7I and Tn72. Thus we find that each transposon has the same sequence of restriction sites as Tn7. From the 'left' end of each transposon these are: EcoRI, HindIII, BamHI, HindIII and BamHI, their distances from that end being $2 \cdot 7$, $4 \cdot 0,5.3,5.9$ and $6 \cdot 0$ Mdal, respectively, for $\operatorname{Tn} 7 \mathrm{I}$, and $2 \cdot 7,4 . \mathrm{I}, 5.5,6 \cdot \mathrm{I}$ and $6.3 \mathrm{Mdal}$, respectively, for Tn72. Within experimental error (bearing in mind the indirect nature of the measurements) these values are not significantly different from the distances of $2 \cdot 7,3 \cdot 8$, $5 \cdot 2,5.8$ and $5 \cdot 9$ Mdal estimated for Tn7 (Barth \& Grinter, 1977).

\section{Orientation of $T n 7 \mathrm{I}$ and $T n 72$ insertion}

Because of the asymmetry of the restriction sites on these transposons, the above calculations enable one to determine their orientation of insertion. We have previously found that $\mathrm{Tn}_{7}$ is inserted in the same orientation in all the (now more than 40 ) transposition RP4 plasmids that we have examined (Barth \& Grinter, 1977, and unpublished data). Tn7I and $\operatorname{Tn} 72$ were also found to be in this orientation (Fig. I).

\section{DISCUSSION}

We have identified two plasmids from different sources, determining $\mathrm{Tp}^{\mathrm{r}}$ and $\mathrm{Sm}^{\mathrm{r}}$, from which we demonstrated transposition of these markers, initially to RP4. Sequential transposition of $\mathrm{Tp}^{\mathrm{r}}$, from the $\mathrm{RP}_{4}$ derivatives was demonstrated in a rec $A$ host, to the bacterial chromosome and thence to $\mathrm{R} 702$. Thus we conclude that these sequences are transposed by a specific mechanism, independent of the recA gene product. We have designated the transposons from $\mathrm{R}_{72 \mathrm{I}}$ and $\mathrm{pBW} \mathrm{I}$ as $\mathrm{Tn} 7 \mathrm{I}$ and $\mathrm{Tn} 72$ respectively. They are indistinguishable from $\operatorname{Tn} 7$ on the following criteria: (i) they determine the same resistances; (ii) they have the same molecular mass; (iii) each has a single EcoRI site, two HindIII sites and two BamHI sites; (iv) these restriction sites are in the same order and at the same relative distances from one another.

Tn7 has multiple sites of insertion into plasmid RP4. These are not randomly placed around its circular map, but tend to concentrate into 'hot spots' (Barth \& Grinter, 1977). In the two transposition plasmids we have examined, Tn7I and $\operatorname{Tn} 72$ were inserted into $\mathrm{RP}_{4}$ at two of these 'hot spots' (Fig. I). This is consistent with our conclusion that Tn7I and $\operatorname{Tn} 72$ are very closely related or identical to $\operatorname{Tn} 7$.

The plasmids originally carrying $\operatorname{Tn} 7, \operatorname{Tn} 7 \mathrm{I}$ and $\operatorname{Tn} 72$ are all clearly distinguishable by molecular weight and other properties (Table I). They belong to two incompatibility groups, although all determine I pili. R72I and pBW I are very similar and may have a common origin. The $E$. coli strain carrying $\mathbf{R} 72$ I was isolated from a human urinary tract infection whereas $\mathrm{pBW}$ I came from $E$. coli from a trimethoprim-treated calf, so there is no obvious epidemiological relationship between them. However, $\mathrm{R}_{483}$ differs from $\mathrm{R}_{72} \mathrm{I}$ and $\mathrm{pBW}$ in its incompatibility properties as well as molecular weight, and it is improbable that all three plasmids are descended from a common ancestor that had already acquired Tn7. Thus we 
suggest that $\mathrm{Tn} 7$ has been transposed in nature between compatible plasmids. We doubt whether there is any significant correlation between the presence of $\operatorname{Tn} 7$ (or $\operatorname{Tn} 7 \mathrm{I}$ or $\operatorname{Tn} 72$ ) and the production of $\mathrm{I}$ pili, since $\mathrm{Tn} 7$ is readily transposable to the $E$. coli chromosome and to plasmids of other incompatibility groups (Barth et al., 1976). Further search may reveal this transposon in other naturally occurring plasmids.

Evidence for the world-wide distribution of $\operatorname{TnA}$ is well documented (Heffron et al., I975 $b$; Matthew \& Hedges, 1976). Other transposons encoding resistance to antibiotics have been described, for example Tnio carries tetracycline resistance (Kleckner et al., 1975). Tetracycline resistance genes are very common in plasmids, but information as to whether this has resulted from the spread of a particular transposon is lacking. The observations reported here are further evidence that transposons may be responsible for the rapid spread of drug resistances.

We are grateful to Nigel Grinter for tcchnical assistance and to Mrs Beryl West, Wellcome Research Laboratories, Berkhamstead, Hertfordshire, for pBW I. Transposon numbers were allocated by the Plasmid Reference Centre, Stanford University, U.S.A. This w'ork was supported by a grant from the Medical Research Council.

\section{REFERENCES}

Bachmann, B. J. (1972). Pedigrees of some mutant strains of Escherichia coli KI2. Bacteriological Reviews 36, 525-557.

BARTh, P. T. \& Grinter, N. J. (1974). Comparison of the deoxyribonucleic acid molecular weights and homologies of plasmids conferring linked resistance to streptomycin and sulphonamides. Journal of Bacteriology 120, 6I 8-630.

BARTh, P. T. \& GRINTER, N. J. (1977). A map of plasmid $\mathrm{RP}_{4}$ derived by insertion of transposon C. Journal of Molecular Biology 113, 455474.

Barth, P. T., Datta, N., Hedges, R. W. \& Grinter, N. J. (I976). Transposition of a DNA sequence encoding trimethoprim and streptomycin resistances from $\mathrm{R}_{4} 83$ to other replicons. Journal of Bacteriology 125, 800-810.

Coetzer, J. N. ( 1972). Genetics of the Proteus group. Annual Review of Microbiology 26, 23-54.

Coetzee, J. N., Datta, N. \& Hedges, R. W. (1972). $\mathrm{R}$ factors from Proteus rettgeri. Journal of General Microbiology 72, 543-552.

Cohen, S. N. (1976). Transposable genetic elements and plasmid evolution. Nature, London 263, $73 \mathrm{I}-738$

DATTA, N. \& BARTH, P. T. (1976). Hfr formation by I-pilus-determining plasmids in Escherichia coli KI2. Journal of Bacteriology 125, 81 I-817.

DAtTA, N. \& Hedges, R. W. (1972). Host ranges of $\mathrm{R}$ factors. Journal of General Microbiology 70 , 453-460.

Datta, N., Hedges, R. W., Shaw, E. J., Sykes, R. B. \& Richmond, M. H. (I97I). Properties of an $\mathrm{R}$ factor from Pseudomonas aeruginosa. Journal of Bacteriology 108, 1244-1249.

Falkow, S., Guerry, P., Hedges, R. W. \& Datta, N. (1974). Polynucleotide sequence relationships among plasmids of the I compatibility complex. Journal of General Microbiology 85, 65-76.

Gotiesman, M. M. \& Rosner, J. L. (I975). Acquisition of a determinant for chloramphenicol resistance by coliphage lambda. Proceedings of the National Academy of Sciences of the United States of America 72, 5041-5045.

Hedges, R. W. \& DatTA, N. (1973). Plasmids determining I pili constitute a compatibility complex. Journal of General Microbiology 77, 19-25.

Hedges, R. W. \& JACOB, A. E. (1974). Transposition of ampicillin resistance from $\mathrm{RP}_{4}$ to other replicons. Molecular and General Genetics 132, $3 \mathrm{I}-4 \mathrm{O}$.

HefFron, F., Rubens, C. \& Falkow, S. (1975a). Translocation of a plasmid DNA sequence which mediates ampicillin resistance: molecular nature and specificity of insertion. Proceedings of the National Academy of Sciences of the United States of America 72, 3623-3627.

Heffron, F., Sublett, R., Hedges, R. W., Jacob, A. E. \& FALKOW, S. $(1975 b)$. Origin of the TEM betalactamase gene found on plasmids. Journal of Bacteriology 122, 250-256.

Jobanputra, R. S. \& DatTA, N. (1974). Trimethoprim resistance factors in enterobacteria from clinical specimens. Journal of Medical Microbiology 7, I 69-177.

Kleckner, N., Chan, R. K., Tye, B.-K. \& Botstein, D. (1975). Mutagenesis by insertion of a drugresistance element carrying an inverted repetition. Journal of Molecular Biology 97, 561-575.

Kopecko, D. J. \& COHEN, S. N. (1975). Sitespecific $\operatorname{rec} A$-independent recombination between bacterial plasmids : involvement of palindromes at the recombinational loci. Proceedings of the National Academy of Science of the United States of America 72, 1373-1377.

Matthew, M. \& Hedges, R. W. (1976). Analytical isoelectric focusing of $\mathrm{R}$ factor-determined $\beta$ lactamases: correlation with plasmid compatibility. Journal of Bacteriology 125, 713-718.

Novick, R. P., Clowes, R. C., Cohen, S. N., Curtiss, R., III, DatTa, N. \& Falkow, S. (1976). Uniform nomenclature for bacterial plasmids: a proposal. Bacteriological Reviews 40, I68-189. 